\title{
Determination of the Physical Activity Levels of Taekwondo Coaches
}

\author{
Şükran ARIKAN¹, Yusuf BARSBUĞA ${ }^{1}$, Serkan REVAN¹ \\ Selcuk University, Faculty of Sport Science, Konya, Turkey. \\ Address Correspondence to S, Revan, e-mail: serkanrevan@gmail.com
}

\begin{abstract}
The aim of this study is to determine the physical activity levels of taekwondo trainers. The total of 544 (132 women, 412 men) coaches participated in the trainer development seminars organized by Turkey Taekwondo Federation participated as volunteers in this research. The physical activity levels of the participants were determined with the short form of the International Physical Activity Questionnaire (UFAA). SPSS 22.0 statistical package program was used to evaluate the data obtained within the scope of the research. The data were analyzed by Kolmogorov-Smirnov test for normality. The MannWhitney $\mathrm{U}$ test was used because the data were not distributed normally and the significance level was accepted as 0.05 . According to the research findings, 3.2\% of the trainers had low physical activity level, $61.4 \%$ had moderate and $35.5 \%$ had high physical activity level. There were statistically significant differences in mean age, height and body weight $(p<0,05)$, no significant difference was found between male and female trainers in sitting, walking, moderate physical activity, high intensity physical activity and total physical activity scores ( $>0.05$ ). It can be said that most of the taekwondo coaches have moderate physical activity levels.
\end{abstract}

Key words: Taekwondo, Coache, International Physical Activity Questionnaire

\section{INTRODUCTION}

Extreme sedentary behavior became a dominant and common feature of modern life. As chronic diseases and premature mortality rates increase, the negative effects of increasing sedentary lifestyle on public health increase (1). In adults, there is strong evidence that there is a relationship between mortality rate due to sedentary or inactive life, fatal and non-fatal cardiovascular diseases, type 2 diabetes, and metabolic syndrome, as well as there is evidence of a moderate association with ovarian, colon and intrauterine cancers $(5,14)$. The World Health Organization (WHO) has reported that inadequate physical activity is one of the most important risk factors for death worldwide, globally, one in four adults are not sufficiently active, and more than $80 \%$ of the world's adolescent population is physically inactive (34).

Physical activity levels are often monitored to assess the health attitudes of the population and their relationship to health status, including mortality and disease rates. It is required to assess physical activities accurately to determine current activity levels and changes in the population and to determine the effectiveness of interventions designed to increase activity levels (26).

Physical activity surveys have practical value to identify conditions in which increase in physical activity would be beneficial and to monitor changes in population activity. However, this use may be made possible by the development of standard tools to record low-intensity activities specific to sedentary populations and bring consistent biological meanings to terms such as light, moderate and heavy exercise (29). The short form of the International Physical Activity Questionnaire (IPAQ) is a frequently used method for assessing physical activity in large-scale epidemiological studies $(3,25,28)$.

Regularly performed physical activities are becoming more and more important within the scope of betterment and protection of the health. It is important for the coaches who have undertaken great tasks in improving the performances of their athletes and creating a sports culture to lead a healthy life and to convey this exemplary life to their 
athletes. The aim of this study is to determine the physical activity levels of taekwondo coaches.

\section{MATERIAL \& METHOD}

Population of the study and sample group: While population of the study is consisting of 3500 taekwondo coaches working in Turkey, the sample group is consisting of a total of 544 coaches (132 females, 412 males) who have participated to the Taekwondo Federation of Turkey organized seminars.

Data Collection Tools: In order to obtain personal data, the information form created by the researcher was used, while the physical activity levels of the participants were determined by the International Physical Activity Questionnaire (IPAQ) short form.

\section{International Physical Activity Survey (IPAQ):}

IPAQ- short form was used to determine the physical activity level of the subjects. This questionnaire, which was developed to find out the types of physical activity of the individual during daily life, includes questions related with the time spent for physical activity with the last 7 days. It questions how often an individual does sports, exercise or recreational activities in his spare time, at work, at home, and going from one place to another. For this survey, the validity and reliability study in Turkey was conducted on university students by Öztürk (22). Information is obtained about the time spent in sitting, walking, moderate intensity physical activity (MIPA) and high intensity physical activity (HIPA). The evaluation of all activities is based on the fact that each activity is performed at least 10 minutes at a time. A score of "METminutes/week is obtained by multiplying the minutes, days and MET value (multiples of rest oxygen consumption). Physical activity levels are classified as low (<600 MET-min/week), moderate (600-3000 MET-min/week) and high (> 3000 MET$\mathrm{min} /$ week) (11).

\section{Statistical Analysis}

SPSS 22.0 statistical package program software was used to evaluate the data obtained within the scope of the research. An analysis by KolmogorovSmirnov test was conducted to determine whether data has normal distribution. Mann Whitney U test was used because the data did not show normal distribution and significance level was accepted as 0.05 .

\section{RESULTS}

$75.7 \%(n=412)$ of the coaches participated in the study were male and $24.3 \%(\mathrm{n}=132)$ were female participants. It was found that $45.6 \%$ ( $\mathrm{n}=$ 248 ) of the participants were 41 years and older, while $32.5 \%(n=177)$ were between $31-40$ years of age. It was observed that the majority of the coaches were mainly consisting of participants graduated from primary, secondary and high schools (Table 1).

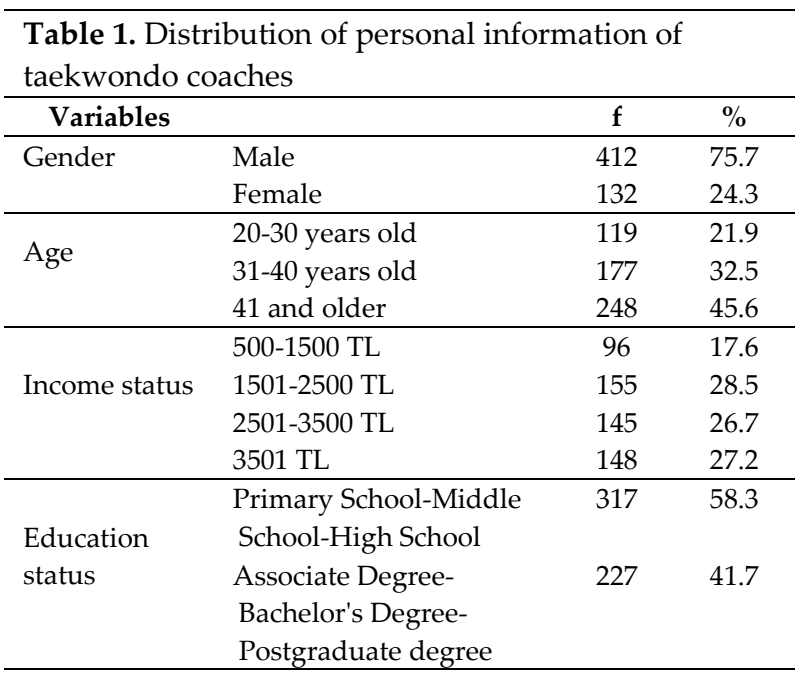

According to the body mass index values of the participants, it was found that $72 \%$ of females were normal, $17.4 \%$ were overweight and $3.8 \%$ were obese. It was found that $35.7 \%$ of the males were normal, $49.5 \%$ were overweight and $13.8 \%$ were obese (Table 2).

Table 2. Distribution of body mass index values of taekwondo coaches by gender variable

\begin{tabular}{|c|c|c|c|c|c|c|}
\hline & & \multicolumn{4}{|c|}{ Body Mass Index } & \multirow[b]{2}{*}{ Total } \\
\hline & & Thin & Normal & $\begin{array}{c}\text { Over- } \\
\text { weight }\end{array}$ & Obese & \\
\hline \multirow{3}{*}{$\frac{0}{3}$} & $f$ & 4 & 147 & 204 & 57 & 412 \\
\hline & $\%$ & $1.0 \%$ & $35.7 \%$ & $49.5 \%$ & $13.8 \%$ & $100.0 \%$ \\
\hline & Total $\%$ & $0.7 \%$ & $27.0 \%$ & $37.5 \%$ & $10.5 \%$ & $75.7 \%$ \\
\hline \multirow{3}{*}{ 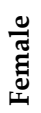 } & $f$ & 9 & 95 & 23 & 5 & 132 \\
\hline & $\%$ & $6.8 \%$ & $72.0 \%$ & $17.4 \%$ & $3.8 \%$ & $100.0 \%$ \\
\hline & Total \% & $1.7 \%$ & $17.5 \%$ & $4.2 \%$ & $0.9 \%$ & $24.3 \%$ \\
\hline
\end{tabular}

It was found that the majority of both male and female coaches $(61.4 \%)$ participated in the study had minimum active physical activity level (Table $3)$. 
Table 3. Physical activity levels of taekwondo coaches by gender variable

\begin{tabular}{|c|c|c|c|c|c|}
\hline & \multicolumn{4}{|c|}{ Physical Activity Level } \\
\hline & & Inactive & $\begin{array}{c}\text { Minimum } \\
\text { Active }\end{array}$ & $\begin{array}{c}\text { Very } \\
\text { Active }\end{array}$ & Total \\
\hline \multirow{3}{*}{$\bar{\pi}$} & f & 15 & 253 & 144 & 412 \\
\hline & $\%$ & $3.6 \%$ & $61.4 \%$ & $35.0 \%$ & $100.0 \%$ \\
\hline & $\sim$ Total \% & $2.8 \%$ & $46.5 \%$ & $26.5 \%$ & $75.7 \%$ \\
\hline \multirow{3}{*}{ 駡 } & f & 2 & 81 & 49 & 132 \\
\hline & $\%$ & $1.5 \%$ & $61.4 \%$ & $37.1 \%$ & $100.0 \%$ \\
\hline & Total \% & $0.4 \%$ & $14.9 \%$ & $9.0 \%$ & $24.3 \%$ \\
\hline
\end{tabular}

As a result of examining the coaches by gender variable, a significant difference was observed in the mean of age, height and body weight in favor of male participants $(\mathrm{p}<0.05)$, but no significant difference was found between the HIPA, MIPA, walking, sitting and total PA averages $(p>0.05)$ (Table 4).

\begin{tabular}{|c|c|c|c|c|c|c|}
\hline & Gender & $\mathbf{N}$ & Mid. & $\mathrm{Z}$ & $\mathrm{U}$ & p \\
\hline \multirow{2}{*}{ Age } & Male & 412 & 40.6 & \multirow{2}{*}{-5.449} & \multirow{2}{*}{18633.5} & \multirow{2}{*}{$0.000^{*}$} \\
\hline & Female & 132 & 35.3 & & & \\
\hline \multirow{2}{*}{$\begin{array}{l}\text { Height } \\
(\mathrm{cm})\end{array}$} & Male & 412 & 174.7 & \multirow{2}{*}{$\begin{array}{c}- \\
13.653\end{array}$} & \multirow{2}{*}{5792} & \multirow{2}{*}{$0.000^{*}$} \\
\hline & Female & 132 & 164.4 & & & \\
\hline \multirow{2}{*}{$\begin{array}{l}\text { Body } \\
\text { weight } \\
(\mathrm{kg})\end{array}$} & Male & 412 & 80.5 & \multirow{2}{*}{$\begin{array}{c}- \\
13.482\end{array}$} & \multirow{2}{*}{6020} & \multirow{2}{*}{$0.000^{*}$} \\
\hline & Female & 132 & 62.3 & & & \\
\hline \multirow{2}{*}{$\begin{array}{l}\text { HIPA } \\
\text { (MET- } \\
\text { min/week) }\end{array}$} & Male & 412 & 914.4 & \multirow{2}{*}{-0.191} & \multirow{2}{*}{26907} & \multirow{2}{*}{0.848} \\
\hline & Female & 132 & 904.5 & & & \\
\hline \multirow{2}{*}{$\begin{array}{l}\text { MIPA } \\
\text { (MET- } \\
\text { min/week) }\end{array}$} & Male & 412 & 877.7 & \multirow{2}{*}{-0.712} & \multirow{2}{*}{26086} & \multirow{2}{*}{0.476} \\
\hline & Female & 132 & 958.6 & & & \\
\hline \multirow{2}{*}{$\begin{array}{l}\text { Walking } \\
\text { (MET- } \\
\text { min/week) }\end{array}$} & Male & 412 & 885 & \multirow{2}{*}{-1.501} & \multirow{2}{*}{24843} & \multirow{2}{*}{0.133} \\
\hline & Female & 132 & 964.9 & & & \\
\hline \multirow{2}{*}{$\begin{array}{l}\text { Sitting } \\
\text { (MET- } \\
\text { min/week) }\end{array}$} & Male & 412 & 544.4 & \multirow{2}{*}{-0.208} & \multirow{2}{*}{26662.5} & \multirow{2}{*}{0.835} \\
\hline & Female & 132 & 546.4 & & & \\
\hline \multirow{2}{*}{$\begin{array}{l}\text { Total PA } \\
\text { (MET- } \\
\text { min/week) }\end{array}$} & Male & 412 & 2677 & \multirow{2}{*}{-1.448} & \multirow{2}{*}{24917} & \multirow{2}{*}{0.148} \\
\hline & Female & 132 & 2828.1 & & & \\
\hline \multicolumn{7}{|c|}{$\begin{array}{l}\text { *(p<0.05), HIPA: High intensity physical activity, MIPA: } \\
\text { Moderate intensity physical activity, PA: Physical activity, } \\
\text { Total PA = HIPA + MIPA + Walking }\end{array}$} \\
\hline
\end{tabular}

\section{DISCUSSION \& CONCLUSION}

In this study conducted to determine the physical activity levels of the Taekwondo coaches, it is found that $3.2 \%$ of the participants were inactive, $61.4 \%$ were minimum active, $35.5 \%$ were very active and there was no significant difference between male and female coaches in respect of high physical activity, moderate physical activity, in walking, sitting and total physical activity scores.
In studies conducted on different occupational groups, Hartung et al. (10) reported that, $62 \%$ of adult, male cooks and $58 \%$ of office workers were in over weighted/obese group for their body mass index average. In a different study conducted on office workers, $0.4 \%$ of the participants were considered to be underweight, $57.3 \%$ were normal, $37.3 \%$ were overweight and 5.1\% were obese (19). Pappas et al. (24) found that the health profiles of nurses in Greece were relatively weak for this occupational group. The researchers also reported that approximately one third of nurses $(n=353$, age $=$ $36 \pm 5,6$ ) were overweight or obese, which could have a negative impact on their ability to improve health in the patient population. In a study conducted on academic members, $2.8 \%$ of the participants were underweight, $44.8 \%$ were normal, $41 \%$ were overweight and $11.4 \%$ were obese (12). When the gender variable is taken into consideration, it is reported that female teachers and academic members in different disciplines were normal weight and male teacher and academic members were overweight $(4,21,30)$. According to World Health Organization data, 39\% of adults aged 18 and older are reported to be overweight and 13\% are obese (35). In our study, $41.7 \%$ of the coaches were found to be overweight and $11.4 \%$ were found to be obese. According to gender variable, $17.4 \%$ of female coaches were overweight, $3.8 \%$ were obese, $49.5 \%$ of male coaches were overweight and $13.8 \%$ were obese. It was seen that our results matched up with these studies.

Many researchers examined physical activity levels of employees in different occupational groups. Kayapinar (15), in her study determined the healthy lifestyle behaviors and physical fitness levels of football coaches, established that the participants were conscious about healthy lifestyle behaviors, however they were not able to apply them in their social lives and physical activities of those were insufficient, their body composition parameter were at health risks limits, especially obesity is increasing rapidly after their active athletic periods come to the end. Similarly, it was reported that $68.9 \%$ of tennis referees had low physical activity levels, $24.4 \%$ were adequate and $6.7 \%$ were inactive. When physical activity levels were examined according to gender, $70.5 \%$ of females have low, $20.7 \%$ have adequate and $8.8 \%$ have inactive levels and $67.8 \%$ of male individuals have low, $26.8 \%$ have adequate and $5.4 \%$ have inactive levels (18). In our study, $3.2 \%$ of the coaches have 
inactive level, $61.4 \%$ have minimum and $35.5 \%$ have very high activity level. According to the gender variable, it was observed that the majority of male and female individuals had minimum activity level.

In a study conducted on teachers from different disciplines, it was reported that $17.1 \%$ were not physically active, $63.9 \%$ had low physical activity level and 19\% had sufficient physical activity level to protect their health (30). It was observed that male physical education teachers had higher levels of physical activity compared to females, whereas moderate physical activity rates were similar in both genders (6).

In a study examining the participation of the academic members serving in different faculties to the physical activity, $57.5 \%$ of the faculty members of the Faculty of Theology and Education Faculty, $55 \%$ of the academic members of the Faculty of Medicine and $22.5 \%$ of the academic members of the Faculty of Agriculture did not have physical activity during the day (31). In a different study, physical activity participation rates of academic members were at $39 \%$ inactive, $50 \%$ less active, $11 \%$ physically active levels (12). Contrary to these studies, Özüdoğru (23) reported that both academic (75.9\%) and administrative staff $(81.9 \%)$ defined themselves as very active.

In the study conducted to determine the healthy lifestyle behaviors of health professional, the lowest score was taken from the exercise sub-dimension, while only $22.8 \%$ of the participants were interested in sports and $58.9 \%$ did not exercise at all (33). Likewise, it was reported that the lowest score of the nurses was taken from the exercise sub-dimension and only $4.3 \%$ of them performed regular physical exercise (20). In a different study, it was determined that $32.1 \%$ of the nurses were not physically active, $48 \%$ had low physical activity level and $19.9 \%$ had sufficient physical activity level (16). In the study conducted on Catalan health personnel, $31.5 \%$ of the medical group, $28.1 \%$ of the support staff, $24.7 \%$ of the nurses and $19 \%$ of the administrative staff were reported to have a low activity level (17). In terms of physical activity level, $53.9 \%$ of the female individuals working at the hospital desk were not active, $61.4 \%$ of the males had low activity and only $5.8 \%$ of the whole group had sufficient physical activity. Researchers point out that the study revealed that low level of physical activity leaded to a sedentary lifestyle and increased the risk of obesity (7).

Turk J Sport Exe 2019; 21(2): 270-275

(4) 2019 Faculty of Sport Sciences, Selcuk University
In the research carried out on employees working at desks and working on feet in different occupational groups in public and private organizations, it was reported that the participation of males in sports activities was higher than that of females, there was an accumulation of moderate activities in both female and male individuals and there was no participation in very high levels of physical activities by female individuals (13). Similarly, it is reported that $48.6 \%$ of office workers are inactive, $43 \%$ have low level and $8.2 \%$ have sufficient activity level (19). Esin and Aktaş (8) reported that as a result of the systematic review, the overweight rate of the employees was between $36 \%$ $-56 \%$ and the physical activity level of $42.5 \%$ was insufficient. The researchers established that although the health behaviors of individuals working in different business lines differ, the factors related to the individual and working conditions affecting health behaviors are similar and therefore these factors should be taken into consideration when planning occupational health programs to improve the health of the employees.

No significant difference was found between male and female coaches in our study in sitting, walking, moderate physical activity, high physical activity and total physical activity scores according to the results obtained from IPAQ. However, unlike our study, Mutlu et al. (18) concluded that total, highly intense, moderate and moderately intense physical activity levels and walking activities of male tennis referees were higher than female referees. They did not found any significant difference in the sitting time variable. Similarly, in a different study, it was found that intense physical activity, total physical activity score, and walking score averages of male individuals working at a desk had higher values than female individuals. It was found that there was no significant difference in moderate physical activity and sitting time (32). Moreover, while the duration of intense, moderate and total physical activity of young adult males was higher than that of females, no statistically significant difference was found between walking and sitting periods of females and males (9). In addition to assessing physical activity and sedentary behavior, assessing sitting time is a new and important area for preventive medicine. Population surveys that monitor lifestyle behaviors should include sitting time measurements in physical activity screenings. Moreover, particularly low and middle income level countries that initiated 
monitoring activities, the use of objective measures to detect sedentary and physical activity behaviors is encouraged (3). Şanlı and Atalay Güzel (30) reported that the sitting time of female teachers (319.6 $\mathrm{min}$ ) was significantly higher than that of male teachers (278.1 min). Likewise, Arrkan and Revan (2) found that the sitting time of female individuals (409.6 min) was significantly higher than that of male individuals (353.3 min) in their studies investigating the relationship between physical activity levels and body composition of students studying at the faculty of sports sciences. Contrary to these studies, no significant difference was found between male and female individuals in respect of the sitting time variable of Turkish tennis referees (18) and individuals working at desks (32). In our present study, in line with these studies, no significant difference was observed between the sitting time of female (546.4 min) and male (544.4 min) coaches. However, the sitting time of taekwondo coaches is quite high compared to the individuals participating in other studies.

Our study has some limitations. The first is that the study is cross-sectional, and evaluations are performed with the scales that the coaches complete themselves. This circumstance limits the interpretation and generalization of our results. Another limitation is that the physical activity levels of the coaches participating in the research were determined only by the International Physical Activity Questionnaire. Physical activity is a multidimensional behavior and no evaluation method can capture all its dimensions. To obtain a more global estimate of physical activity, multiple assessment methods should be used. The use of multiple methods may contribute to understanding the relationship between different techniques (27).

As a consequence, more than half of the taekwondo coaches were found to be in the over weighted/obese group and the majority of them were at least active level group. The physical activity habits of the coaches, which are expected to form an example to the society and their athletes in every aspect, are also important for social development. It may be suggested that coaches, who will be role models for the society in healthy life, try to be a good role model by correcting their negative or incomplete behaviors.

\section{REFERENCES}

1. Archer E, Blair SN. Physical activity and the prevention of cardiovascular disease: from evolution to epidemiology. Prog Cardiovasc Dis, 2011, 53(6):387-96.

2. Arıkan Ş, Revan S. Relationship between physical activity levels and body compositions of university students. Turkish Journal of Sport and Exercise, 2019, 21(1): 67-73.

3. Bauman A, Ainsworth BE, Sallis JF, Hagströmer M, Craig CL, Bull FC, et al. The descriptive epidemiology of sitting. A 20-country comparison using. The International Physical Activity Questionnaire (IPAQ). Am J Prev Med, 2011, 41(2):228-35.

4. Canbolat D. Öğretmenlerde fiziksel aktivite düzeyi ve benlik saygısının incelenmesi. Selçuk Üniversitesi Sağlık Bilimleri Enstitüsü Yüksek Lisans Tezi, Konya, 2018.

5. De Rezende LF, Rodrigues Lopes M, Rey-López JP, Matsudo VK, Luiz Odo C. Sedentary behavior and health outcomes: an overview of systematic reviews. PLoS One, 2014, 21;9(8): e105620.

6. Durukan Ö, Şahin G, Durukan H. Physical education teachers; physical activity level and affecting factors (the example of Çanakkale). Turkish Journal of Sport and Exercise, 2016, 18 (1):103-109.

7. Erdoğan M, Certel Z, Güvenç A. Masa başı çalışanlarda fiziksel aktivite düzeyi: obezite ve diğer özelliklere göre incelenmesi (Akdeniz Üniversitesi Tıp Fakültesi Hastanesi Örneği). Spor Hekimliği Dergisi, 2011,46: 97-107.

8. Esin MN, Aktaş E. Çalışanların sağlık davranışları ve etkileyen faktörler: Sistematik inceleme, İ.Ü.F.N. Hem. Dergisi, 2012, 20 (2): 166-176.

9. Genç A, Şener Ü, Karabacak H, Üçok K. Kadın ve erkek genç erişkinler arasında fiziksel aktivite ve yaşam kalitesi farklılıklarının araştırılması. Kocatepe Tıp Dergisi 2011,12: 145-150.

10. Hartung D, Stadeler M, Grieshaber R, Keller S, Jahreis G. Work and diet related risk factors of cardiovascular diseases: comparison of two occupational groups. J Occup Med Toxicol, 2010, 22;5:4.

11. IPAQ. Guidelines for data processing and analysis of the International Physical Activity Questionnaire (IPAQ). Short and long forms, 2005. Available from file://C:/Users/asus/Downloads/scoring_protocol\%20(1).pdf

12. Kalkavan A, Özkara AB, Alemdağ C, Çavdar S. Akademisyenlerin fiziksel aktiviteye katılım düzeyleri ve obezite durumlarınin incelenmesi. International Journal of Science Culture and Sport,2016, 4(1): 329-339.

13. Karaca A. Ankara ilinde çalışan bireylerin bedensel etkinlik düzeyleri. Gazi Beden Eğitimi ve Spor Bilimleri Dergisi, 2000, 3:11-20.

14. Katzmarzyk PT, Church TS, Craig CL, Bouchard C. Sitting time and mortality from all causes, cardiovascular disease and cancer. Med Sci Sports Exerc, 2009, 41(5):998-1005.

15. Kayapınar M. Futbol antrenörlerinin sağlıklı yaşam biçimi davranışları ve fiziksel uygunluk düzeyleri ile bazı kan değerlerinin karşılaştırılması. Fırat Üniversitesi Sağlık Bilimleri Enstitüsü Beden Eğitimi ve Spor Anabilim Dalı, Yüksek Lisans Tezi, Elazı̆̆, 2012. 
16. Kılınç F. Hemşirelerde fiziksel aktivite düzeyi ile yaşam kalitesi arasındaki ilişkinin değerlendirilmesi. Hasan Kalyoncu Üniversitesi Sağllk Bilimleri Enstitüsü, Yüksek Lisans Tezi, Gaziantep, 2018.

17. Molina Aragonés JM, Sánchez San Cirilo S, Herreros López M, Vizcarro Sanagustín D, López Pérez C. Prevalence of physical activity in primary health care workers of Catalonia. Semergen, 2017, 43(5):352-357.

18. Mutlu TO, Saygın Ö, Erdoğan M, Şentürk HE, Göral K. Faal türk tenis hakemlerinin fiziksel aktivite özelliklerinin cinsiyet, kategori ve beden kitle indeksine göre araştırılması. CBÜ Beden Eğitimi ve Spor Bilimleri Dergisi, 2012, 7(2):1-7.

19. Önen Tekin H. Ofis çalışanlarında fiziksel aktivite düzeyinin kas iskelet sistemi rahatsızlıklarına etkisi., Dicle Üniversites Sağlık Bilimleri Enstitüsü Halk Sağlığı Anabilim Dalı, Yüksek Lisans Tezi, Diyarbakır, 2018.

20. Özkan S, Yılmaz E. Hastanede çalışan hemşirelerin sağlıklı yaşam biçimi davranışları. Fırat Sağlık Hizmetleri Dergisi, 2008, 3(7):89-105

21. Öztürk $M, A v c 1 S$, Ataman $H$. İstanbul üniversitesi öğretim elemanlarının ünvanlarına ve meslek gruplarına göre fiziksel aktivite düzeylerinin incelenmesi. İ.Ü Spor Bilim Dergisis, 2003,11:183-187.

22. Öztürk M. Üniversitede eğitim öğretim gören öğrencilerde uluslararası fiziksel aktivite anketinin gecerliliği ve güvenirliği ve fiziksel aktivite düzeylerinin belirlenmesi. Hacettepe Üniversitesi Yüksek Lisans Tezi, Ankara, 2005.

23. Özüdoğru E. Üniversite personelinin fiziksel aktivite düzeyi ile yaşam kalitesi arasındaki ilişkinin incelenmesi. Mehmet Akif Ersoy Üniversitesi Eğitim Bilimleri Enstitüsü Beden Eğitimi ve Spor Öğretimi Programı, Yüksek Lisans Tezi, Burdur, 2013.

24. Pappas NA, Alamanos Y, Dimoliatis ID. Self-rated health work characteristics and health related behaviours among nurses in Greece: a cross sectional study. BMC Nurs, 2005, 20(4):8.

25. Pengpid S, Peltzer K, Kassean HK, Tsala Tsala JP, Sychareun V, Müller-Riemenschneider F. Physical inactivity and associated factors among university students in 23 lowmiddle and high-income countries. Int J Public Health, 2015, 60(5):539-49.

26. Prince SA, Adamo KB, Hamel ME, Hardt J, Connor Gorber S, Tremblay M. A comparison of direct versus self-report measures for assessing physical activity in adults: a systematic review. Int J Behav Nutr Phys Act, 2008, 6(5):56.

27. Rod K. Dishman RK, Richard A. Washburn RA \& Dale A. Schoeller DA. Measurement of physical activity. QUEST, 2001, 53 (3): 295-309.

28. Sigmundová D, Sigmund E, Hamřík Z, Kalman M, Pavelka J, Frömel K. Sedentary behaviour and physical activity of randomised sample of czech adults aged 20-64 years: IPAQ and GPAQ studies between 2002 and 2011. Cent Eur J Public Health, 2015, 23:91-6.

29. Shephard RJ. Limits to the measurement of habitual physical activity by questionnaires. Br J Sports Med, 2003;37:197-206.

30. Şanlı E, Atalay Güzel N. Öğretmenlerde fiziksel aktivite düzeyi-yaş, cinsiyet ve beden kitle indeksi ilişkisi. Gazi Beden Eğitimi ve Spor Bilimleri Dergisi, 2009, XIV(3):23-32.

31. Uluöz E, Yilmaz CY, Dinç, ZF. Farklı fakültelerde görev yapan akademisyenlerin fiziksel aktiviteye katılım durumlarının incelenmesi. International Journal of Cultural and Social Studies, 2017, 3(Special Issue), 326-336

32. Vural Ö. Masa başı çalışanlarda fiziksel aktivite düzeyi ve yaşam kalitesi ilişkisi. Gazi Üniversitesi Sağlık Bilimleri Enstitüsü, Yüksek Lisans Tezi, Ankara, 2010.

33. Yalçınkaya M, Gök Özer F, Yavuz Karamanoğlu A. Sağlık çalışanlarında sağlıklı yaşam biçimi davranışlarının değerlendirilmesi. TSK Koruyucu Hekimlik Bülteni, 2007, 6: 409-420.

34. https://www.who.int/news-room/fact-sheets/detail/physicalactivity, WHO (World Health Organization 2019)

35. https://www.who.int/en/news-room/factsheets/detail/obesity-and-overweight, WHO (World Health Organization 2019) 